\title{
CORRESPONDENCE
}

\section{PENETRATING CORNEAL GRAFT}

\section{To the Editorial Committee of the British Journal of OpHTHALMOLOGY}

DEAR SIRs-In your issue of September, 1953, Mr. I. C. Michaelson draws timely attention to the difficulty of even penetration by the trephine into the anterior chamber in fullthickness keratoplasty. Michaelson turns this difficulty to advantage by placing the initial area of penetration according to various pathological conditions of the host cornea (B.J.O., 1953, 37, 562).

The ideal of even and simultaneous penetration of the anterior chamber by the trephine at right angles to the horizontal corneal plane is rarely achieved with safety. It is assisted by the use of a very sharp trephine which does not cause the host eye to rotate even when the cornea is thick and irregular, by firm fixation with multiple tooth forceps, such as the Barraquer pattern, and by smooth, light, and even finger-and-thumb rotation of the trephine.

We have found further assistance at East Grinstead by a simple manoeuvre which we think is worth putting on record.

When the trephine has been accurately centred on the host cornea, before rotation is begun, the assistant crooks an index finger over the end of the trephine, in line with its body and with the centre of the host cornea. However the eye tends to deviate from position during rotation of the trephine, the assistant's finger always maintains position in line with the centre of the cornea, and the surgeon is thus able to see at once if his trephine is not being maintained at strict right angles to the plane of section. It is easy tocorrect this adjustment by keeping the trephine always in line with the finger above it. It has been found that about five-sixths of the circumference of the graft section is constantly cut by this simple aid. The remainder is completed by the Arruga knife, taking care not to cut a shelf, or by the Rycroft scissors. Since the best section is made by the trephine, as much as possible of the circumference should by cut by rotation of the trephine, which should never be lifted until the anterior chamber is opened. When such a section is combined with a punch graft an accurate fit is obtained without shelves or tags.

Yours faithfully,

B. W. RYCROFT.

G. J. RoMANES.

Corneo-Plastic Unit and Regional Eye Bank,

QUEEN Victoria HosPital,

East Grinstead, Sussex.

September 18, 1953.

\section{BOOK REVIEWS}

Tumours of the Orbit. By R. G. Ingalls. 1953. Pp. 410, 140 figs. Thomas, Springfield, Ill., U.S.A., and Blackwell Scientific Publications, Oxford. (83s.)

This book on orbital tumours and " pseudo-tumours " comprises a readable and instructive analysis of 216 eye histories, the material for most of which was gathered from the pathological laboratories of the Institute of Ophthalmology of the Presbyterian Hospital, New York. Each type of tumour affecting the orbital tissues or its walls or invading it from neighbouring parts receives a chapter to itself; each is discussed under the headings of aetiological factors, anatomical location in the orbit, general appearance and behaviour, 
symptoms to which it gives rise, and histological characteristics and each chapter contains a series of well-illustrated and fully annotated case reports and a summary of recent literature. The result is an instructive book, the richer because of the large amount of space devoted to the personal experience of the author. The illustrations, particularly the photo-micrographs, are abundant and unusually good, and a useful bibliography is appended.

Le gliome de la rétine et les pseudogliomes. Etude clinique, génétique, et thérapeutique. By Marc-Adrien Dollfus and Bertranne Auvert. 1953. Pp. 521, 9 plates, 101 figs. Masson, Paris. (Frs 3,300; 68s.)

The conception and practice of the French Ophthalmological Society in setting each year a subject for a report is admirable. Such a report is published before the Society's annual congress at which its authors read a resumé of their work. Since 1926 the Society has produced a succession of excellent monographs of the highest quality, and to this distinguished series of reports is now added the work of Dr. Dollfus on retinoblastoma and Dr. Auvert on pseudoglioma. Their contribution covers most thoroughly all the literature and they add to this a wealth of material from their own extensive experiences in large clinics in Paris. This monograph contains much of academic and clinical interest and the authors are to be congratulated on their industry in collecting data through communications with ophthalmologists all over the world, on the excellent arrangement of their material, and on their choice of illustrations. Their labours have clearly earned them an exalted place both as ophthalmologists and as participants in the splendid series of the Society's publications.

Their monograph is, and will remain, a most important source of reference concerning such tragic ocular diseases as retinoblastoma and the pseudogliomas.

It is produced in the style which is characteristic of the good work of Masson et Cie.

William Cheselden. By Sir Zachary Cope. 1953. Pp. 112, 24 figs, 60 refs. Livingstone, Edinburgh. (20s.)

William Cheselden (1688-1752), one of the great London general surgeons of his generation, will always be remembered in ophthalmology as being the first to devise and practise the operation of iridotomy for an occluded pupil; nor was this the only original contribution of note he made to surgery. His life story has been recently told in a delightful book by Sir Zachary Cope, who chose this subject for his Vicary Lecture at the Royal College of Surgeons in October, 1952. Cope devotes a chapter of this monograph to Cheselden's ophthalmological activities; and interesting reading it is. There is a good description of Cheselden's technique for the couching of cataract in 1725 (Daviel did not publish his description of extraction until 1748). At this time the general view was that cataract was a film in front of the lens; but Cheselden dissected an affected eye and satisfied himself that the disease comprised an opacity of the entire lens.

A human touch, not without interest, concerns the capsule of the lens: in the first edition of his famous "Anatomy " Cheselden stated that the lens had nø covering capsule, and a certain Dr. Kennedy called on the surgeon at his home to satisfy him that a capsule was in fact present. Kennedy wrote " that he made no great reply thereto, but that he colour'd ". In later editions Cheselden altered his description of the lens, but his informant complained that he had made no acknowledgement of the source of his information.

The book is worth reading if only for Cheselden's descriptions of the "Observations made by a young Gentleman who was born blind, or lost his sight so early that he had no remembrance of ever having seen, and was couched between thirteen and fourteen years of age ". Looking at paintings, the boy " was amazed when he found those parts, which by their light and shadow appeared now round and uneven, felt only flat like the rest, and asked which was the lying sense, feeling or seeing?" 